\title{
Opportunities and constraints of functional assessment of mined land rehabilitation
}

\author{
P.D. Erskine Centre for Mined Land Rehabilitation, The University of Queensland, Australia \\ A.T. Fletcher Centre for Mined Land Rehabilitation, The University of Queensland, Australia \\ B. Seaborn Salkhit Wind Farm, Leighton LLC, Mongolia
}

\begin{abstract}
This paper presents a general overview of the functional attributes of rehabilitated open-cut coal mine lands. It provides an evaluation of how classical soil analysis techniques and landscape function analysis (LFA) have been applied to ecosystems on heavily modified mined landscapes. It also compares the landscape position and placement of LFA transects to high-resolution imagery captured by an unmanned aerial vehicle. LFA was originally developed as a method for assessing soil surface conditions in the rangelands of Australia and has since been applied in other countries, ecosystems and, more recently, mine sites. The method uses quickly observed soil surface features to estimate the status of three important soil functional processes (particularly stability, infiltration and nutrient cycling), which have been proposed as indicators of ecosystem rehabilitation success. For mine site rehabilitation, LFA index scores are typically interpreted as trends over time and compared with unmined reference communities. This paper suggests that LFA transects and the LFA-generated scores do not adequately reflect the functional success of rehabilitated coal mine lands. The utility of these monitoring methods in constructed landscapes should be critically examined before future application.
\end{abstract}

\section{$1 \quad$ Introduction}

Open-cut coal mining occurs in many areas of the world where coal resources occur close to the surface. In Australia, both thermal and metallurgical coals are mined using open-cut methods to ensure that multiple coal seams can be effectively recovered. This type of mining is considered to be very cost-effective but it also removes all existing ecosystems, soil layers and overburden (referred to as spoil) that lie above the coal seam. Rehabilitation practices generally include reshaping of spoil waste dumps, topsoil replacement, deep ripping and application of seed and fertilisers. However, after more than 40 years of open-cut mining in the coal-rich Bowen Basin in central eastern Australia, not a single mine has been successfully rehabilitated and closed. Additionally, guidelines developed by government and industry more than seven years ago to begin the process of progressive rehabilitation (Carroll and Minchinton, 2006) to reduce rehabilitation bonds have not resulted in a single rehabilitated spoil dump being signed off. One of the reasons for this impasse is both the reluctance of government to take on residual risk of rehabilitation and the lack of agreed indicators and completion criteria demonstrating that the sites are safe, stable, non-polluting and sustainable.

Operators of coal mines in the Bowen Basin need to determine what indicators effectively demonstrate the sustainability of their rehabilitated lands and develop robust completion criteria with these indicators. The Queensland Environmental Protection Agency defined indicators as 'something that can be measured and audited according to an established protocol and used to evaluate changes in a system' (QLD EPA, 2007). Dale and Beyeler (2001) suggest that indicators should meet the following criteria in order for them to be effective. First, the indicator must be easily measured, resulting in an easily applied and relatively inexpensive measure of the system. Second, they must also be sensitive to stress on the system, allowing for small changes in the system to be recognised if necessary. Further, they should be able to predict changes that can be averted by management actions, integrate several aspects of a system, have a known 
response to disturbances, change over time and have low variability in response. The suite of indicators should also be representative of the structure, function and composition of the ecological system. The Commonwealth Scientific and Industrial Research Organisation (CSIRO) define good indicators by qualities including:

- Having an agreed, scientifically sound meaning.

- Representing an environmental aspect of importance to society.

- Telling us something important and having a meaning that is readily understood.

- Having a sound and practical measurement process.

- Helping focus information to answer important questions.

- Assisting decision making by being effective and cost-efficient to use (CSIRO, 1999).

All indicators should provide information about conditions and, over time, may identify the direction of changes. One series of indicators potentially applicable to mine sites is landscape functional analysis (LFA), as the methodology is widely suggested as a tool to assess the functional status of an ecosystem (Tongway and Ludwig, 2011). It consists of three components encompassing a conceptual framework of how landscapes function, a field methodology (Tongway and Hindley, 2004) and a framework for the interpretation of results. The technique has been widely adopted by the mining industry, and results of attempts to validate the approach against more conventional indicators were deemed largely to be positive by Tongway and Hindley (2003).

Conceptually, LFA considers landscape organisation in terms of how vital resources such as soil, nutrients and water are distributed, regulated and utilised across a landscape by biotic and abiotic processes (Tongway and Ludwig, 2011). In most Australian landscapes, water is the strongest force that influences the flow of resources, and the landscape is comprised of 'source' zones where water runs off entraining and transporting loose materials and 'sink' zones where resources are accumulated and absorbed (Tongway and Ludwig, 2011). Thus, the landscape can be characterised by the level of resource control. Typically, dysfunctional landscapes are characterised by large areas of bare soil and few obstructions that can capture and utilise resources. Functional landscapes have a high degree of resource utilisation and control, low overall resource losses from runoff and erosion processes and fertile patches where resources are concentrated (Tongway and Hindley, 2004).

The LFA assessment methodology is described in detail in Tongway and Hindley (2004). Briefly, transects up to $100 \mathrm{~m}$ in length are established and described initially in terms of landscape organisation comprising 'patches' of inferred resource accumulation and 'interpatches' of inferred resource loss. Obstructions to overland flow (e.g., stones, logs or perennial grass clumps) with a basal width of greater than $2 \mathrm{~cm}$ are also recorded. For each patch or interpatch type, five replicate areas are scored according to several soil surface conditions. These include an assessment of ground surface cover, litter cover, the degree of litter incorporation, litter movement, microtopography, surface hardness, cryptogam cover, soil texture, soil aggregate stability and crusting. Soil surface condition scores are then combined to produce three indices of (i) stability or resistance to erosion, (ii) infiltration and (iii) nutrient cycling (Table 1). The stability index indicates the soil's ability to withstand erosive forces. The infiltration index reflects the soil's capacity to promote surface infiltration. Soil textural properties, surface characteristics and, to a significant degree, litter cover and incorporation contribute to the calculation of the index. The nutrient cycling index reflects the processes of organic matter cycling, not of soil nutrient content. The amount of litter, its origin and degree of incorporation contribute largely to this index (Table 1).

For mine rehabilitation, LFA index scores are typically interpreted as a trend over time in relation to scores observed in suitable unmined reference communities. Actual index values do not in themselves indicate the functional state of a site but must be interpreted relative to scores for unmined reference sites, or relative to the same site at different monitoring times (Tongway and Hindley, 2004). 
Table 1 Derivation of the LFA stability, infiltration and nutrient cycling indices (Tongway and Hindley, 2004)

\begin{tabular}{|c|c|}
\hline LFA Index & Soil Surface Characteristics used to Derive the Index (Scale) \\
\hline Stability & $\begin{array}{c}\text { Soil cover }(1-5)+\text { litter cover }(1-10)+\text { cryptogam }(1-4)+\text { crust broken- } \\
\text { ness }(1-4)+\text { erosion features }(1-4)+\text { deposition features }(1-4)+\text { surface } \\
\text { nature }(1-5)+\text { slake }(1-4)\end{array}$ \\
\hline \multirow[t]{2}{*}{ Infiltration } & $\begin{array}{l}\text { Perennial basal cover }(1-4)+\text { litter, origin and incorporation }(1-30)+ \\
\text { microtopography }(1-5)+\text { slake }(1-4)\end{array}$ \\
\hline & + texture $(1-4)+$ surface nature $(1-10)$ \\
\hline Nutrient cycling & Perennial basal cover $(1-4)+$ litter, origin and \\
\hline & incorporation $(1-30)+$ cryptogam $(1-4)+$ surface nature $(1-5)$ \\
\hline
\end{tabular}

This paper compares a selection of mine site LFA indices reported by Tongway and Ludwig (2006) and Tongway and Hindley (2004) with unpublished data from the Centre for Mined Land Rehabilitation (Seaborn 2005) for Gregory coal mine in the Bowen Basin to assess the utility of LFA in this environment. Additional LFA data were also collected as part of a rehabilitation monitoring program for Collinsville coal mine, and they are assessed and compared with high-resolution imagery to assess the representativeness of LFA transects. The primary research question addressed by this paper is, Does LFA methodology generate indicators that adequately demonstrate the sustainability of a rehabilitated coal mine?

\section{$2 \quad$ Methods}

\section{$2.1 \quad$ Study sites}

Rehabilitation data from two coal mines in the Bowen Basin, central Queensland, Australia, are used in this paper. The first mine, Gregory $\left(23^{\circ} 11^{\prime} \mathrm{S} 148^{\circ} 22^{\prime} \mathrm{E}\right)$, has been operated by the BHP Billiton Mitsubishi Alliance since 1979. The mine is in the central region of the Bowen Basin and has a mean maximum temperature of $29.7^{\circ} \mathrm{C}$ and mean annual rainfall of $567 \mathrm{~mm}$ (Bureau of Meteorology, 2013a). The second mine, Collinsville $\left(20^{\circ} 33^{\prime} \mathrm{S}, 147^{\circ} 51^{\prime} \mathrm{E}\right)$, is currently a joint venture between Xstrata Coal, Itochu Coal Resources and Sumitomo and has been operating since 1919. It lies at the northern end of the Bowen Basin and has a mean annual maximum of $30.2^{\circ} \mathrm{C}$ and mean annual rainfall of $718 \mathrm{~mm}$ (Bureau of Meteorology, 2013b). The dominant vegetation types in the region are tropical eucalypt woodlands, brigalow (Acacia harpophylla) forests and anthropogenic grasslands created by forest clearing and the introduction of pasture grasses for cattle grazing. The geology of both mine sites is complex and the coals seams fragmented, allowing operations in relatively small discrete pits (J. Brady, pers. comm.). Historically, both mines have had a variety of rehabilitation methods, but they commonly included reshaping of waste spoil behind active pits, application of topsoil (generally stored for several years), construction of contour banks, ripping to $500 \mathrm{~mm}$, application of fertiliser and seeding with pasture species and tree species. The environmental authorities that these two mines operate under require that they rehabilitate to either grazing land or to self-sustaining native ecosystems. Rehabilitation at both mines is dominated by exotic grass species, predominately Cenchrus ciliaris and Chloris gayana, with sites at Collinsville also generally having higher densities of acacia and eucalyptus trees and shrubs than Gregory.

\subsection{LFA and traditional soil analyses}

LFA data were collected at Gregory coal mine by Seaborn (2005) and at Collinsville by Landloch (2010). Their LFA transects were orientated downslope across a range of rehabilitation ages (see Table 2), and they used a number of sampling points along transects to assess the soil surface features following methodology and criteria set by Tongway (2002). These soil surface feature characteristics were grouped together using the LFA Data Entry Microsoft Excel spreadsheets (Version 2.2), which automatically summarised the data 
on summary sheet and calculated indices (from Table 1) reflecting soil stability, infiltration and nutrient cycling.

Table 2 Rehabilitation age, slope, soil pH and electrical conductivity (EC) at two coal mine sites assessed by landscape function analysis

\begin{tabular}{ccccc}
\hline Site & $\begin{array}{c}\text { Rehab Age } \\
\text { (Years) }\end{array}$ & $\begin{array}{c}\text { Slope } \\
(\%)\end{array}$ & $\begin{array}{c}\text { Soil pH } \\
\text { Range }\end{array}$ & $\begin{array}{c}\text { Maximum } \\
\text { Soil EC (dS/m) }\end{array}$ \\
\hline RehabG1 & 2 & 10 & $7.0-8.0$ & 0.3 \\
RehabG2 & 9 & 10 & $6.9-7.8$ & 0.8 \\
RehabG3 & 16 & 5 & $6.7-7.9$ & 0.1 \\
RehabG4 & 20 & 12 & $6.9-7.8$ & 0.2 \\
Gregory Analogues & - & 3 & $6.8-8.0$ & 0.1 \\
RehabC1 & 2 & 15 & 7.1 & 0.2 \\
Collinsville Analogues & - & $<8$ & $5.0-7.0$ & 0.4 \\
\hline
\end{tabular}

Sampling points used for LFA at Gregory mine were also utilised by Seaborn (2005) to measure soil respiration and infiltration and to collect samples for chemical analysis and aggregate stability as part of the wider Tongway and Hindley (2003) verification study. Soil respiration was conducted following Hartigan (1980) and infiltration rates were measured using methodology detailed by White et al.(1992). Aggregate stability, expressed as mean weight diameter, was calculated after wet sieving as the sum of the percentage of soil on each sieve multiplied by the mean diameter of adjacent sieves, following Chaney and Swift (1984). All soil samples were analysed for $\mathrm{pH}$ and EC (1:5 soil to water ratio) with a hand-held pH/EC meter.

Linear regression was used by Tongway and Hindley's (2003) verification study for data analysis and testing of the reliability of the predictions provided by LFA indices versus traditional soil analysis. Three linear regression graphs are taken from Tongway and Ludwig (2006) and are presented for comparison in the results section of this paper, but these have also been published in Tongway and Hindley (2003) and Tongway and Hindley (2004). The unpublished data from Seaborn (2005) was processed using the same methods to generate linear regressions $p$-values and $R^{2}$ values for all rehabilitation sites at Gregory mine. For successful verification, a significant and positive regression between the LFA and measured variable values was required. Although there is no lower $R^{2}$ value that confirms a relationship, a value greater than 0.8 is considered a good linear model, while an $R^{2}$ of 0.5 suggests that the explanatory variable data only explains $50 \%$ of the response variable.

Additional observation data were obtained from Fletcher (2006), who reviewed the stability of the rehabilitation at Gregory and the maintenance requirements for closure or partial relinquishment of the mine.

\subsection{High-resolution imagery}

Aerial photography was captured by a small remote-piloted aircraft over a rehabilitated area at Collinsville coal mine in July 2012. Traditional colour imagery was collected using a Sony NEX5 camera (16 mm lens, ISO200, 1/500 sec, sunlight white balance) and GPS co-ordinates recorded at the location of each photo. Individual images were geo-referenced and resampled to create an orthophoto mosaic at $5.3 \mathrm{~cm}$ pixel resolution and generate a digital elevation model using photogrammetry software (Pix4D, Switzerland). Erosion gullies at the rehabilitation site, Collinsville 1, were determined using the digital elevation model and orthophoto product in ARCGIS 10.1. A set of annual aerial photos (1999 to 2012) that covered Collinsville mine were used to categorise historic rehabilitation activities and generate rehabilitation age polygons in ARCGIS 10.1. 


\section{Results and discussion}

Rehabilitated land assessed at Gregory coal mine had slopes $12 \%$ or less, slightly alkaline to neutral soil pH and maximum surface soil ECs that were up to eight times higher than analogue sites. Comparatively, the Collinsville rehabilitation site (RehabC1) had a steeper slope, and its soil $\mathrm{pH}$ was equivalent to the analogues sites but the EC was half that of those sites.

The graphs in the Tongway and Ludwig (2006) paper used selected mine sites that best illustrated the relationship of LFA indices with traditional measures of stability, infiltration and nutrient cycling. Figure $1 a$ illustrates the data from a mine site with a significant relationship between aggregate stability and measured stability index. A positive and significant trend was also observed for Gregory mine (Figure 1b), but the spread of the data and coefficient of determination $\left(R^{2}\right)$ less than 0.4 suggest that this relationship is more tenuous at this site.

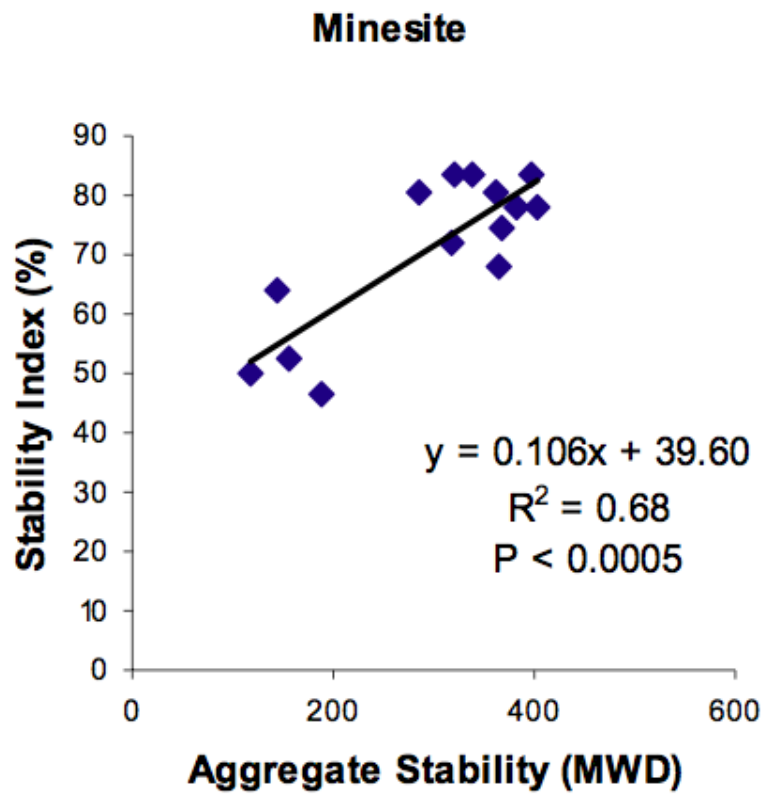

(a)

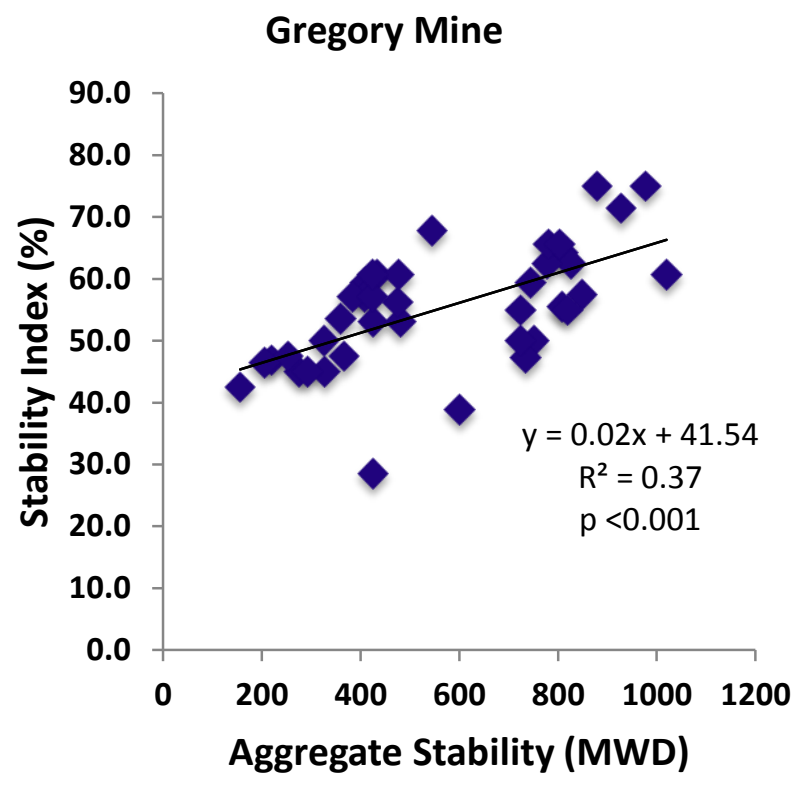

(b)

Figure 1 Relationship between aggregate stability and the stability index at unnamed mine site; (a) in Tongway and Ludwig (2006) and corresponding data at Gregory mine site; and (b) with unpublished data from Seaborn (2005)

The low number of points used by Tongway and Ludwig (2006) in Figure 2a and only moderate levels of verification from four of the nine mine sites assessed by Tongway and Hindley (2003) suggest that this is a difficult ecosystem function to assess. Seaborn (2005) suggests that there were significant technical difficulties measuring infiltration at Gregory and that it was possible that these contributed to the lack of relationship between the infiltration index and measured infiltration (Figure $2 \mathrm{~b}$ ). Evidence from other research (Reynolds et al., 2000) suggests that infiltration is one of the most difficult hydrological parameters to evaluate or measure accurately. Without reliable physical infiltration measures, the likelihood that LFA, using simple surface features, including litter that makes up more than $50 \%$ of the infiltration index (see Table 1), could be an accurate and appropriate measure of soil infiltration is extremely unlikely. 
Minesite

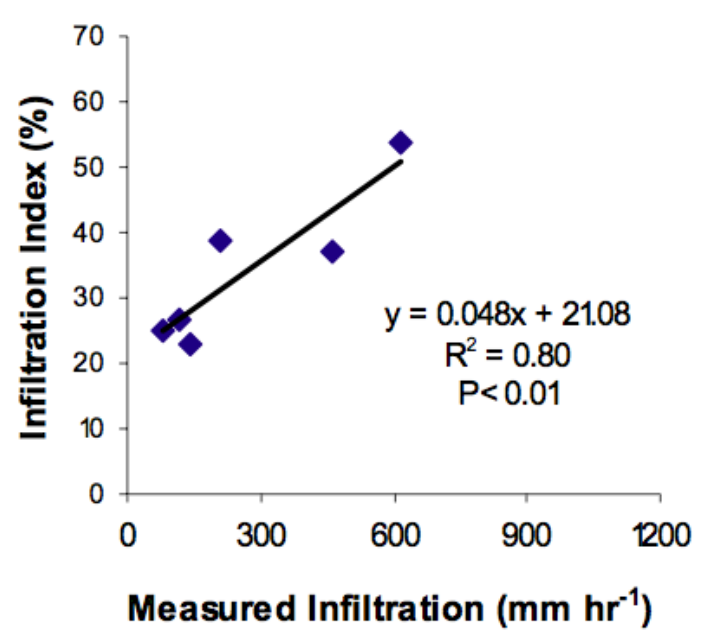

(a)
Gregory mine

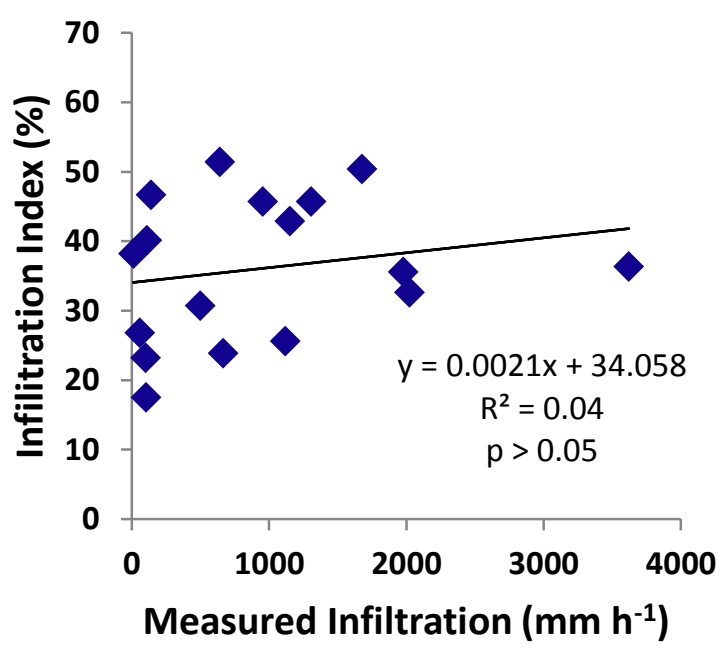

(b)

Figure 2 Relationship between measured infiltration and infiltration index at an unnamed mine site; (a) in Tongway and Ludwig (2006) and corresponding data at Gregory mine site; and (b) with unpublished data from Seaborn (2005)

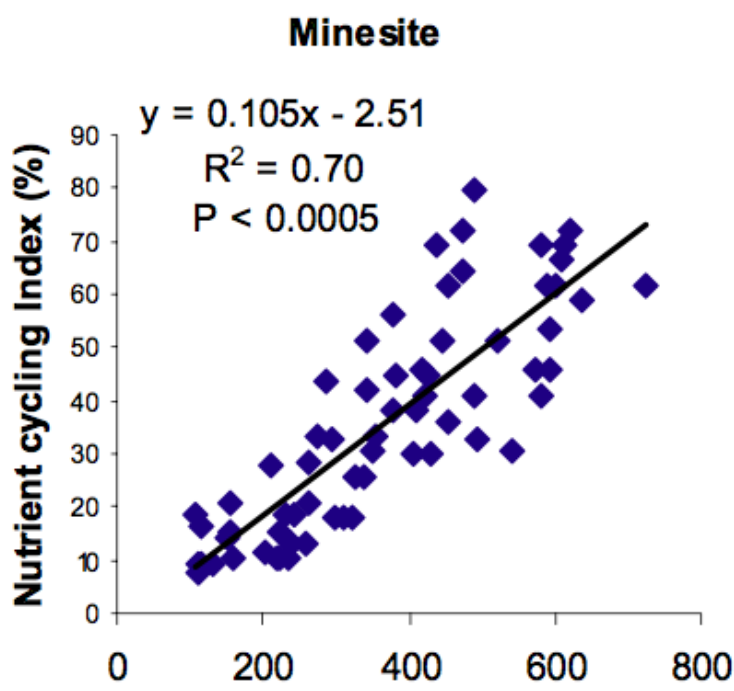

Soil Respiration (mg CO $2 \mathrm{~m}^{-2} \mathrm{hr}^{-1}$ )
Gregory mine

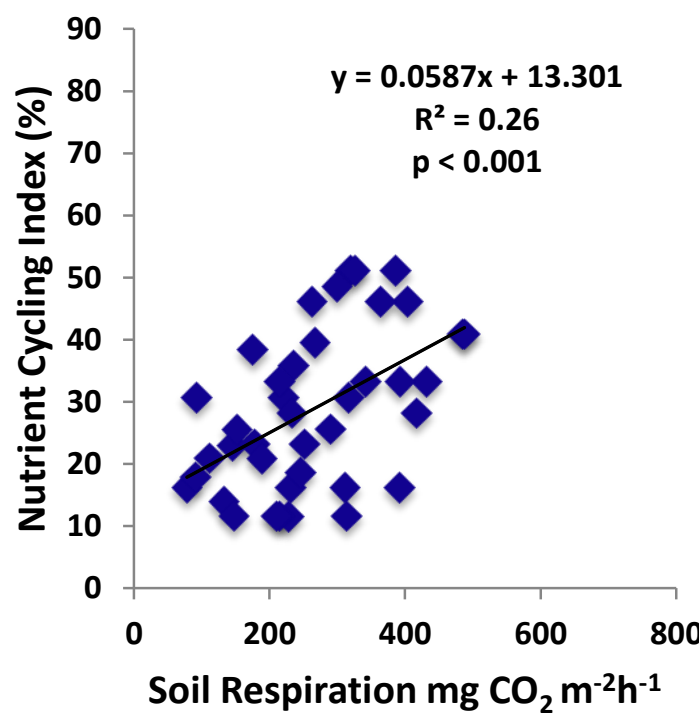

Figure 3 Relationship between nutrient cycling index and soil respiration at an unnamed mine site; (a) in Tongway and Ludwig (2006) and corresponding unpublished data at Gregory mine site; and (b) with unpublished data from Seaborn (2005)

The final comparison of mine site LFA data from Tongway and Ludwig (2006) suggests that soil respiration was closely related to the nutrient cycling index (Figure 3a). There was also a positive and significant relationship observed in the Gregory data (Figure $3 \mathrm{~b}$ ). However, the $\mathrm{R}^{2}$ value was low $(0.26)$, and the variability of the nutrient cycling index (ranging between $11 \%$ and $51 \%$ ) when soil respiration values were near $315 \mathrm{mg} \mathrm{CO}_{2} \mathrm{~m}^{-2} \mathrm{~h}^{-1}$ suggests the utility of this index at Gregory coal mine could not substantiated.

Tongway and Hindley (2004) used the Gove bauxite mine rehabilitation to demonstrate trends in LFA indices over time, and these are illustrated in Figure 4a-4c so that the trajectory of data from Gregory mine 
(Figure 4d-4e) can be compared directly. Trends in each of the LFA indices over time were similar for both mines, with corresponding rapid increases after the first decade of rehabilitation. Although indices were slightly higher at Gove, an interesting feature of these graphs is that when rehabilitation is around 20 years old, the indices of stability, infiltration and nutrient cycling were often substantially higher than those measured for analogue sites. At Gove, Tongway and Hindley (2004) suggest the lower values at the analogue sites are due to constant fires, while we speculate that the higher values for rehabilitation at Gregory may be due to the lack of grazing on the mine site and the accumulation of litter. Taken at face value, these data nonetheless suggest that rehabilitated land is more functional than the non-mined land.

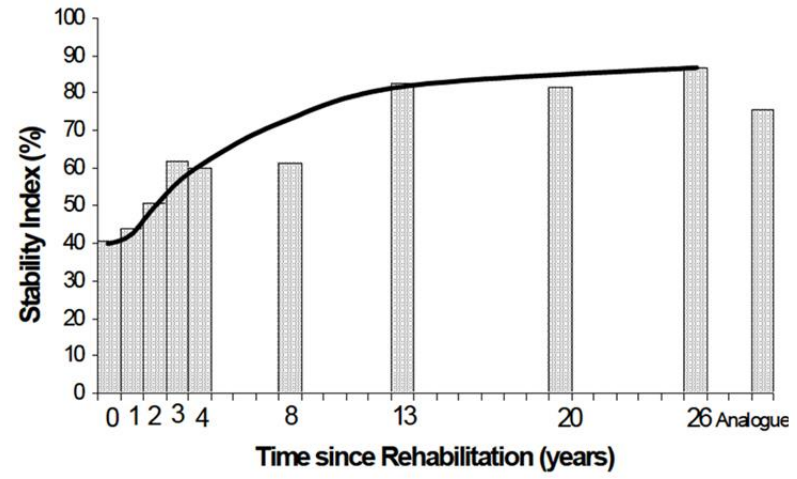

(a)

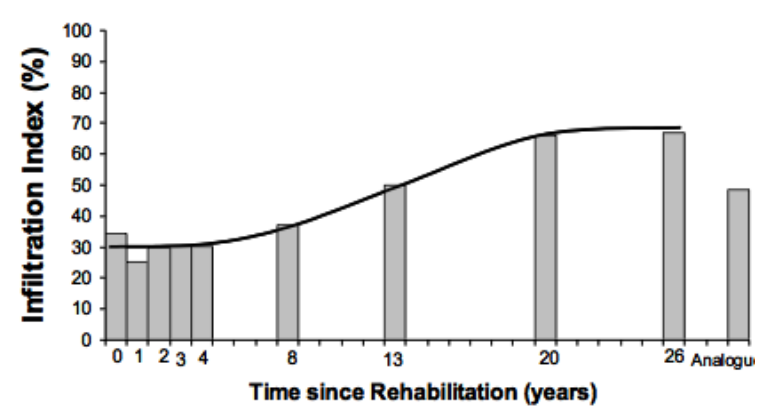

(b)

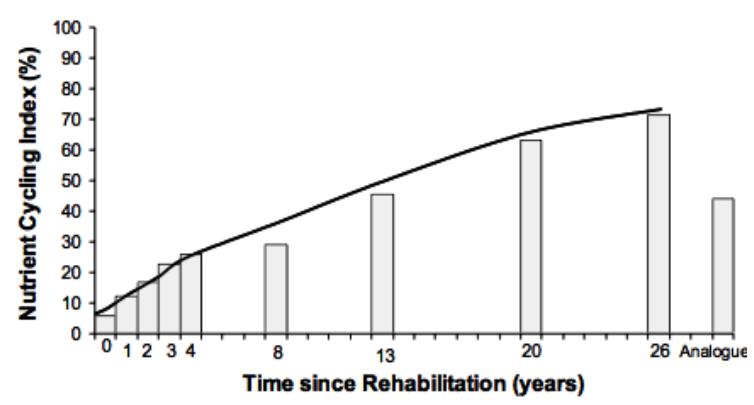

(c)

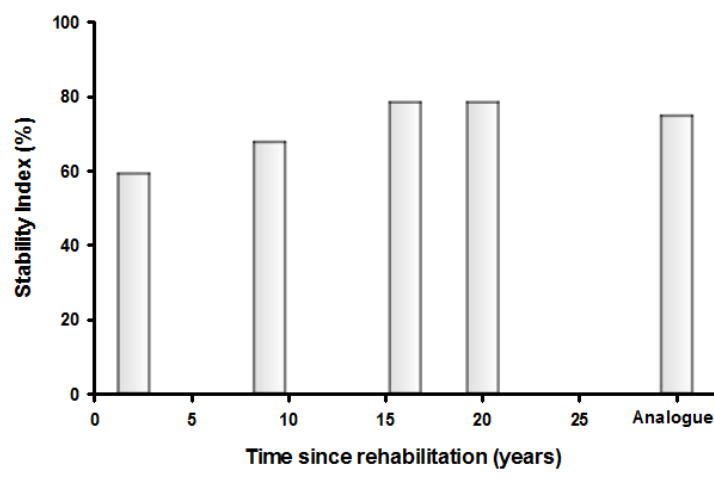

(d)

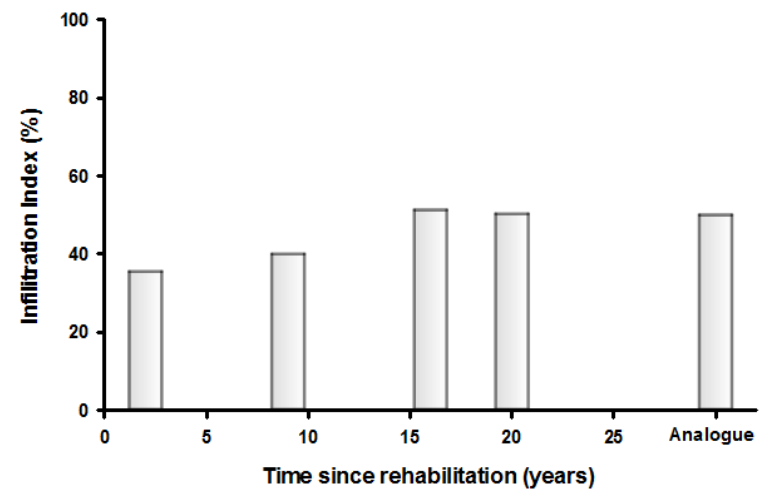

(e)

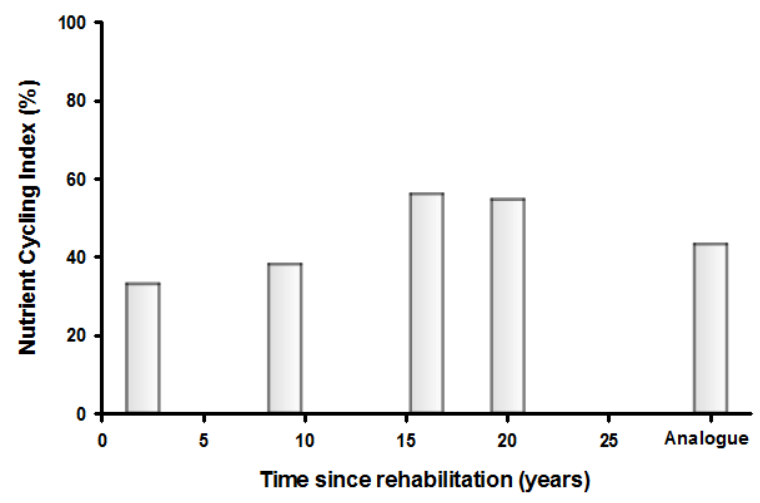

(f)

Figure 4 Relationship between the age of rehabilitation and improvement in LFA indices at Gove mine site; (a-c) reported in Tongway and Hindley (2004) and corresponding LFA indices at Gregory mine site; and (d-f) with unpublished data from Seaborn (2005) 
Evidence from an assessment of rehabilitated land Gregory mine (Fletcher, 2006) suggests that landform stability is generally poor and not even close to analogue sites. Fletcher (2006) also found that the constructed slope angle, material placement and contour banks gradually lead to pipe erosion and regular slope failure (Figures $5 \mathrm{a}$ and $5 \mathrm{~b}$ ). The seemingly false measured improvements in LFA indices at Gregory mine (Figure 4d-f) provide evidence that this methodology may be measuring indicators that cannot contribute to mine closure. As Gregory mine has undergone several attempts to close, without success, the need to identify indicators that provide confidence to government regulators that landform sustainability has or has not been achieved remains critical.

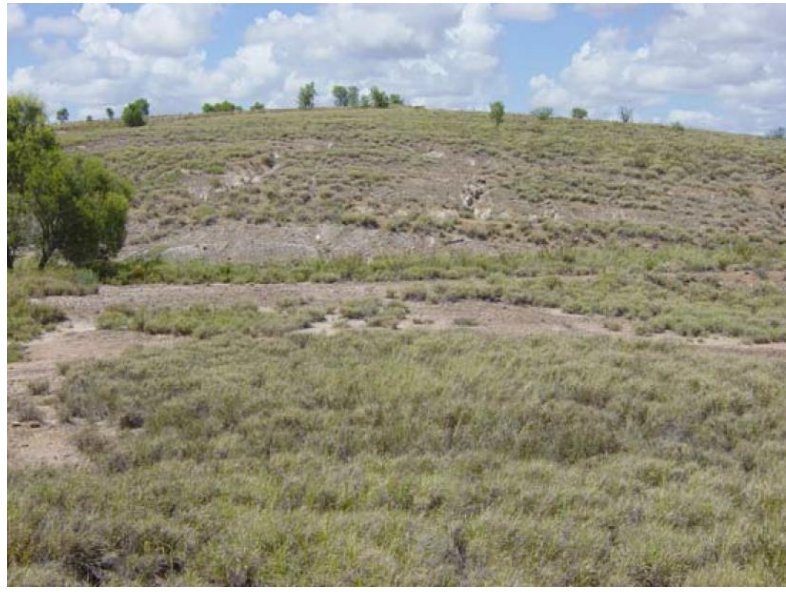

(a)

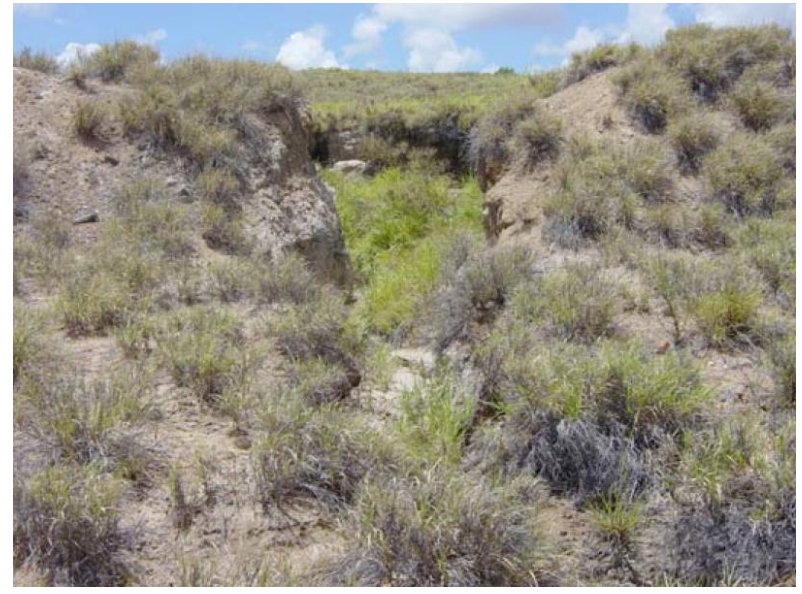

(b)

Figure 5 Images taken by Fletcher (2006) at Gregory coal mine three years after LFA transect data were collected at RehabG1; (a) Illustrates how bank grading and steep slopes have led to the failure of the downhill slope; and (b) demonstrates pipe erosion caused by ponding in the constructed banks

When LFA transects are utilised, they can only cover a relatively small area, which may or may not represent a larger rehabilitation area. However, Tongway and Hindley (2004) suggest that for most sites two transects are sufficient. In practice, however, often only one transect is used for coal mine rehabilitation monitoring, due to difficulties accessing sites and time and cost constraints. The placement of the LFA transects on rehabilitated land also depends on the judgement and background knowledge of the scientist conducting the assessment. The scale and time-dependency of this type of monitoring was evaluated using Landloch (2010) LFA transects at Collinsville. As illustrated in Figure 6, a single LFA transect was placed in the 2008 rehabilitation section of RehabC1, an area that consists of rehabilitation activities conducted from 2003 to 2009 . This age variability means that a single transect cannot be used to assess the success of RehabC1. Nevertheless, for rehabilitation that was only two years old, the calculated LFA stability index for this transect was $66.3 \%$, while analogue sites outside the mine ranged between $68.8 \%$ and $69.2 \%$ (Landloch 2010). This suggests that the rehabilitation was as stable as the surrounding landscape. An assessment of gulley erosion (some of it up to $2.5 \mathrm{~m}$ in depth) using high-resolution imagery and outlined in Figure 6 illustrates that most of RehabC1 was highly unstable and rapidly eroding. The fact that the LFA stability index suggests the opposite would leave any critical government regulator with little confidence that LFA measures any ecological function that informs rehabilitation sustainability or assists with mine closure or lease relinquishment. 


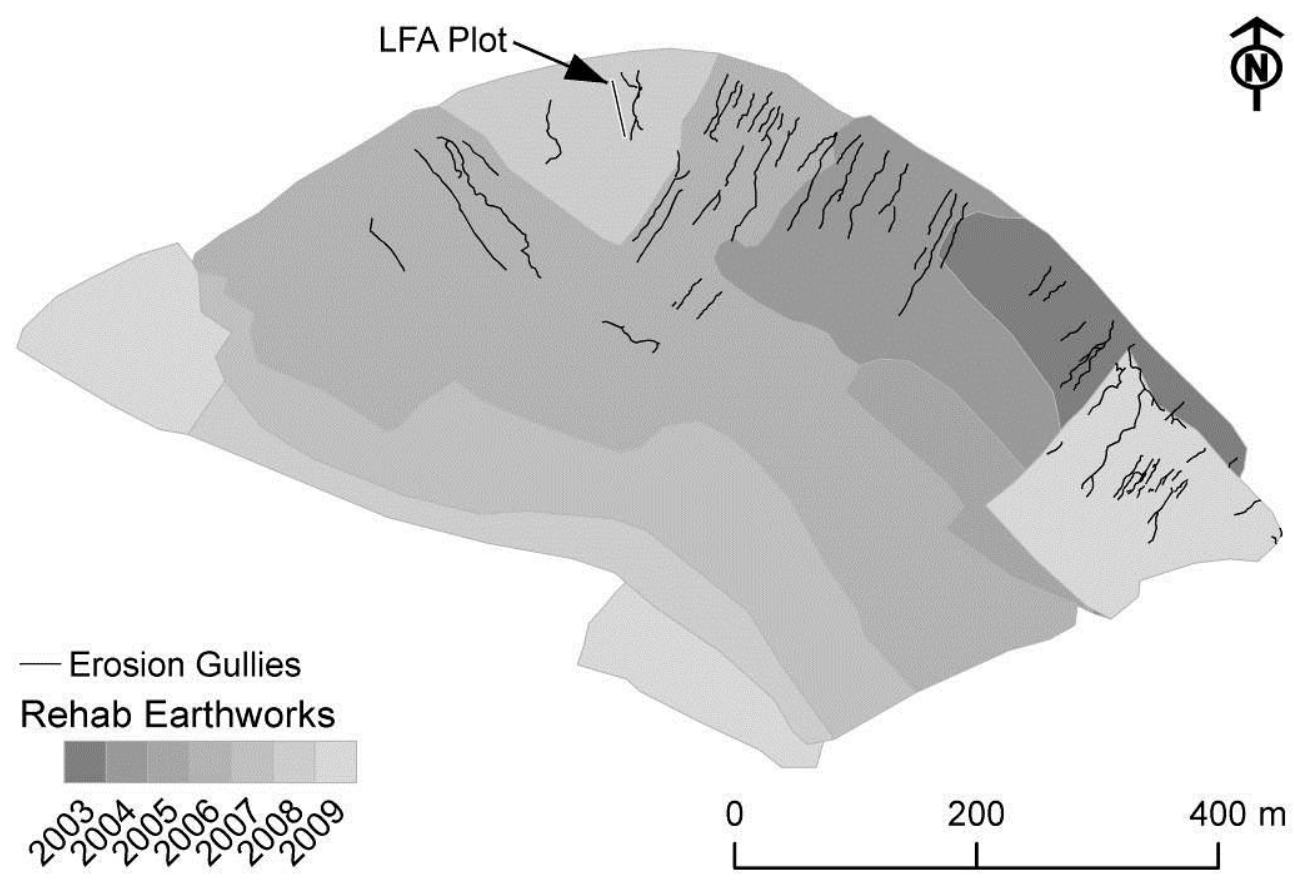

Figure 6 Pattern of earthworks, location of the LFA transect and extent of gulley erosion at RehabC1, a rehabilitated spoil dump at Collinsville coal mine

\section{$4 \quad$ Conclusions}

The conclusion from the data collated in this paper is that it is prudent to use a level of caution if attempting to use indices generated by landscape function analysis when assessing the sustainability of coal mine rehabilitation. The lack of traditional measures that are highly correlated or can verify LFA data, the predictable trends over time as litter accumulates in unmanaged rehabilitation and spatiotemporal issues with the data collected all suggest that there are major limitations to LFA methodology. Papers from an earlier Mine Closure Conference (Nichols, 2006; Mulligan, et al., 2006) found that components of LFA are relatively subjective and inconsistent with measured nutrient pools, suggesting that the ability of the method to be repeatable and meaningful remains questionable. When using the criteria recommended by Dale and Beyeler (2001) and CSIRO (1999) for what constitutes an effective indicator, LFA indices do not

- appear to be sensitive to stress on the system, as they fail to demonstrate the poor slope stability at Gregory and Collinsville,

- provide evidence that they can predict changes and inform management actions,

- have an agreed, scientifically sound meaning,

- focus information to answer important questions, such as how to develop robust and repeatable completion criteria.

Furthermore when they are used in real-world conditions on coal mines, LFA transects under-sample rehabilitated areas and easily miss the underlying variability of different management actions and rehabilitation reworking that regularly occurs on coal mines.

\section{Acknowledgements}

Thanks to Dr Bernie Kirsch for helping to collect data from Gregory and Collinsville mine sites. 


\section{References}

Bureau of Meteorology (2013a) Summary statistics Emerald Airport, viewed 26 April 2013, http://www.bom.gov.au/climate/averages/tables/cw_035264.shtml.

Bureau of Meteorology (2013b) Summary statistics Collinsville Post Office, viewed 26 April 2013, http://www.bom.gov.au/climate/averages/tables/cw_033013.shtml.

Carroll, R. and Minchinton, J. (2006) Progressive rehabilitation of large mines, viewed 26 April 2013, http://www.claytonutz.com.au/publications/newsletters/queensland_energy_and_resources_insights/20060216/progressi ve_rehabilitation_of_large_mines.page.

Chaney, K. and Swift, R.S. (1984) The influence of organic matter on aggregate stability in some British soils, Journal of Soil Science, Vol. 35, pp. 223-230.

CSIRO (Commonwealth Scientific and Industrial Research Organisation) (1999) A Guidebook to Environmental Indicators, viewed 26 April 2013, http://www.csiro.au/csiro/envind/code/pages/04.htm.

Dale, V.H. and Beyeler, S.C. (2001) Challenges in the development and use of ecological indicators, Ecological Indicators, Vol. 1(1), pp. 3-10.

Fletcher, G. (2006) Gregory mine rehabilitation maintenance review, Internal report for BHP Billiton Mitsubishi Alliance, $16 \mathrm{p}$.

Hartigan, J. (1980) Soil respiration as an index of forest floor metabolism, PhD thesis, University of New England.

Landloch Pty Ltd (2010) Ecosystem function analysis (EFA): rehabilitation monitoring on Collinsville coal mine, Queensland, report prepared for Xstrata Coal Pty Ltd, $27 \mathrm{p}$.

Mulligan, D.R., Gillespie, M.J., Gravina, A.J. and Currey, N.A. (2006) An assessment of the direct revegetation strategy on the tailings storage facility at Kidston gold mine, North Queensland, in Proceedings First International Seminar on Mine Closure, A.B. Fourie and M. Tibbett (eds), 13-15 September 2006, Australia, Australian Centre for Geomechanics, Perth, pp. 371-381.

Nichols, O.G. (2006) Developing completion criteria for native ecosystem reconstruction - a challenge for the mining industry, in Proceedings First International Seminar on Mine Closure, A.B. Fourie and M. Tibbett (eds), 13-15 September 2006, Australia, Australian Centre for Geomechanics, Perth, pp. 61-74.

QLD EPA (Queensland Environmental Protection Agency) (2007) Guideline 18: Rehabilitation requirements for mining projects, Queensland Government, $30 \mathrm{p}$.

Reynolds, W.D., Bowman, B.T., Brunke, R.R., Drury C.F. and Tan, C.S. (2000) Comparison of tension infiltrometer, pressure infiltrometer, and soil core estimates of saturated hydraulic conductivity, Soil Science Society of America Journal, Vol. 64, pp. 478-484.

Seaborn, V.C. (2005) An assessment of landscape function analysis as a tool for monitoring rehabilitation success in the mining industry, M. Phil Thesis, University of Queensland, Brisbane, Australia, 205 p.

Tongway, D.J. (2002) Assessing rehabilitation success: a training course to understand, assess and monitor the success of mine rehabilitation using ecosystem function analysis indicators, CSIRO, Sustainable Ecosystems, Canberra.

Tongway, D.J. and Hindley, N. (2003) Indicators of Ecosystem Rehabilitation Success. Stage Two - Verification of EFA Indicators for the Australian Centre for Mining Environmental Research, CSIRO, Sustainable Ecosystems, Canberra.

Tongway, D.J. and Hindley, N. (2004) Landscape function and analysis: procedures for monitoring and assessing landscapes, with special reference to rangelands and minesites, CSIRO, $80 \mathrm{p}$.

Tongway, D.J. and Ludwig, J.A. (2006) Assessment of landscape function as an information source for mine closure, in Proceedings First International Seminar on Mine Closure, A.B. Fourie and M. Tibbett (eds), 13-15 September 2006, Australia, Australian Centre for Geomechanics, Perth, pp. 21-29.

Tongway, D.J. and Ludwig, J.A. (2011) Landscape Function Analysis: Soil-surface Indicators, in The science and practice of ecological restoration restoring disturbed landscapes: putting principles into practice, Island Press, Washington, DC, pp. 145-150.

White, I., Sully, M. and Perroux, K. (1992) Measurement of surface-soil hydraulic properties: disc permeameters, tension infiltrometers, and other techniques, in Advances in Measurement of Soil Physical Properties: Bringing Theory into Practice, Soil Science Society of America, Madison, Wisconsin, USA, pp. 69-103. 